\title{
Chemical treatment of papaya seeds aiming at long-term storage and control of damping off ${ }^{1}$
}

\author{
Silvia de Carvalho Campos Botelho ${ }^{2}$, Silvaldo Felipe da Silveira ${ }^{3}$, Roberto Ferreira da Silva ${ }^{3}$, Alexandre Pio Viana ${ }^{3}$
}

\begin{abstract}
Damping off is a nursery disease of great economic importance in papaya and seed treatment may be an effective measure to control. The aim of this work was to evaluate the quality of papaya seeds treated with fungicides and stored under two environmental and packaging conditions. Additionally, the efficiency of fungicide treatments in the control of damping-off caused by Rhizoctonia solani was evaluated. Papaya seeds were treated with the fungicides Captan, Tolylfluanid and the mixture Tolylfluanid + Captan (all commercial wettable powder formulations). Seeds of the control group were not treated. The seeds were stored for nine months in two conditions: packed in aluminum coated paper and kept at $7 \pm 1{ }^{\circ} \mathrm{C}$ and in permeable kraft paper and kept in non-controlled environment. At the beginning of the storage and every three months the seed quality (germination and vigor tests), emergence rate index, height, dry mass and damping of plants in pre and post-emergence (in contaminated substrate and mycelia-free substrate) were analyzed. Both storage conditions as well as the fungicide treatments preserved the germination and seed vigor. In the infested substrate, seedling emergence was favored by fungicides, but in post-emergence, fungicides alone did not control the damping off caused by R. solani. Symptoms of damping off were not observed in the clean substrate. The results showed that the fungicide treatments may be used to pretreat papaya seed for long-term storage and commercialization.
\end{abstract}

Key words: Carica papaya L., damping off, fungicides, Rhizoctonia solani.

\section{RESUMO}

\section{Tratamento químico de sementes de mamão, visando ao armazenamento prolongado e ao controle do tombamento}

O tombamento é uma doença de viveiro de grande importância econômica na cultura do mamoeiro e o tratamento de sementes pode ser uma medida eficaz para seu controle. Objetivou-se, neste trabalho, avaliar a qualidade de sementes de mamão, tratadas com fungicidas, em formulação pó molhável, e armazenadas sob duas condições de acondicionamento (embalagens) e de ambiente. Adicionalmente, avaliou-se a eficiência do tratamento com fungicidas no controle do tombamento causado por Rhizoctonia solani. Sementes de mamoeiro (cv. Golden) foram tratadas com os fungicidas captan, tolylfluanid e mistura captan+tolylfluanid. Sementes sem tratamento constituíram a testemunha. As sementes foram armazenadas por nove meses em duas condições: (i) acondicionadas em papel aluminizado e mantidas a $7 \pm 1{ }^{\circ} \mathrm{C}$; (ii) acondicionadas em papel permeável tipo kraft e mantidas em ambiente não controlado. No início e a cada três meses, avaliaram-se a qualidade das sementes (testes de vigor e de germinação), a emergência, o índice de velocidade de emergência, a altura, a massa da matéria seca e o tombamento de plantas, em pré e pós-emergência (substrato com e sem inóculo micelial de $R$. solani). Ambas as condições de armazenamento bem como os tratamentos fungicidas preservaram a germinação e o vigor das sementes. No substrato infestado, a emergência de plântulas foi favorecida pelos fungicidas, mas, em pós-emergência, estes, sozinhos, não controlaram o tombamento causado por $R$. solani. Já, em substrato limpo não se observaram sintomas de tombamento. Conclui-se que os tratamentos fungicidas poderão ser utilizados no pré-tratamento de sementes de mamoeiro, para fins de armazenamento prolongado e comercialização.

Palavras-chave: Carica papaya L., damping off, fungicidas, Rhizoctonia solani.

Received: 19/07/2012; Approved: 17/07/2013

1 This work is part of the Master's degree dissertation of the first author presented to UENF.

2 Agronomist, Doctor. Embrapa Agrossilvipastoril, Rodovia MT 222, Km 2,5, Caixa Postal 343, 78550-970, Sinop, Mato Grosso, Brasil. silvia.campos@embrapa.br (corresponding author).

3Agronomist, Doctor. Centro de Ciências e Tecnologias Agropecuárias, Universidade Estadual do Norte Fluminense Darcy Ribeiro, Avenida Alberto Lamego, 2000, 28013-600,

Campos dos Goytacazes, Rio de Janeiro, Brasil. silvaldo@uenf.br; roberto@uenf.br; pirapora@uenf.br 


\section{INTRODUCTION}

The stage of seedling production is essential for the establishment of papaya crop, since damping off is one of the most frequently occurring diseases in the nursery and in the field. The main causative agents of this disease are Rhizoctonia spp., Pythium spp. and Phytophthora spp. Damping off occurs primarily in the warm and moist season and papaya seedling death can occur within few days reaching losses of more than $80 \%$ (Oliveira \& Santos Filho, 2000).

Pathogens attack before or after seedling emergence, resulting in pre- or post-emergence damping-off, respectively. In the pre-emergence damping off, the seed tissues become dark, lose rigidity and rot. In seedlings that emerge from the soil, the symptoms can be observed in the stem, usually in the crown region, causing seedlings to collapse and decay (Bedendo, 1995).

The use of good quality seeds and pathogen-free substrate are effective practices in controlling damping off diseases of fruit seedlings in nurseries (Embrapa, 2012). Seed treatment is also a viable alternative, because of its relative simplicity compared to other methods of plant protection, lower cost and considerable efficiency.

Oliveira et al. (2000) suggested the use of captan for papaya seed protection and Posse (2005) reported that benomyl and the mixture (iprodione + benomyl) were effective in the control of papaya damping off. Campos et al. (2009) evaluated ready-to-use formulations of the fungicides captan, tolylfluanid, thiabendazole, difeconazole, pencycuron and fludioxonil and concluded that they were not toxic to the seeds and seedlings of papaya at the tested concentrations.

Taking into consideration the high seed cost of hybrid papaya varieties currently marketed in Brazil, it is important to study the storage of fungicide-treated seeds, to preserve seed quality and reduce losses by damping off. The objectives of this study were: a) to evaluate the quality of papaya seeds treated with fungicides and stored under two pacckaging and storage conditions up for nine months; and b) to evaluate the efficiency of the chemical treatment in the control of papaya damping-off of caused by $R$. solani, at pre- and post-emergence.

\section{MATERIALS AND METHODS}

\section{Seed origin and treatment with fungicides}

Seeds were obtained from fruits of papaya (Carica papaya), cultivar Golden (Solo group), from the Company Caliman Agrícola S/A, in Linhares, Espírito Santo State, Brazil. The experiments were conducted at the Laboratory of Plant Science and in a greenhouse, Universidade Estadual do Norte Fluminense.
The seeds were treated with the active ingredients captan (5 g kg-1), tolylfluanid (2.5 g kg-1) and captan + tolylfluanid $(5.0+2.5 \mathrm{~g} \mathrm{~kg}-1)$. The fungicides were applied to the seeds in tumbler-type mixer for approximately $10 \mathrm{~min}$. A sample without chemical treatment was used as control.

The treated seeds were packaged and stored under two conditions: 1 - in aluminum coated paper, vacuum packaging, in a BOD at $7 \pm 1{ }^{\circ} \mathrm{C}$ and $70 \pm 5 \%$ relative humidity $(\mathrm{RH}) ; 2$. in permeable kraft paper stored in noncontrolled environment, with temperature ranging between 25 and $27^{\circ} \mathrm{C}$ and relative humidity between 54 and $66 \%$ (UR $=62 \%$ in average). The packages contained between 400 and 450 seeds weighing about 7 g. Evaluations were performed immediately after the treatment and every three months, up to nine months of seed storage.

\section{Seed quality evaluation}

Monitor of treated seed quality during storage was carried out with the following analysis:

a) Moisture content: according to the guidelines of the "Regras para Análise de Sementes" (Brazil, 1992), using three seed samples of $5 \mathrm{~g}$, without chemical treatment.

b) Microbiological analysis (Blotter Test) using 16 replicates of 25 seeds without chemical treatment (Neergaard, 1979). The percentage of seeds infected per genus of fungi was calculated for each storage condition.

c) Germination test: using four replicates of 50 seeds per replicate, placed on two germitest paper sheets and covered with another, wetted with distilled water at a ratio of 2.5:1 (water: substrate), according to Brazil (1992) with modifications. The paper rolls were placed inside transparent polyethylene bags to maintain humidity, in a BOD with temperature $20-30{ }^{\circ} \mathrm{C}(16 \mathrm{~h}$ dark and $8 \mathrm{~h}$ light, respectively). The evaluation and the count of normal seedlings were performed at 14 and 28 days after the test setting and the results expressed as the percentage of normal seedlings.

d) Accelerated Aging Test: in each repetition, 3.5 grams of seeds were evenly distributed on a metallic screen, attached to the upper portion of a plastic box (Germbox $\left.{ }^{\circledR}\right)$ containing $40 \mathrm{~mL}$ of distilled water and covered with a lid. The boxes were incubated in a BOD chamber at a temperature of $44 \pm 1^{\circ} \mathrm{C}$ and $75 \%$ relative humidity for 96 h. Three replicates were performed per treatment. After this period, the seeds were put to germinate, according to the germination test.

The experiment was arranged in a completely randomized design with three replications in a $2 \times 4 \times 4$ factorial with two storage conditions, four fungicide treatments and four storage periods (0,3,6 and 9 months). Data were subjected to analysis of variance ( $\mathrm{F}$ at $5 \%$ 
probability) and the treatments were compared with the polynomial regression analysis.

\section{Control of pre- and post-emergence damping off}

To evaluate the control of damping off, each treatment was tested in three replicates. Each replication consisted of a tray with 96 conical tubes $(53 \mathrm{~cm} 3)$ filled ith Plantmax ${ }^{\circledR}$ commercial substrate up to an inch below the rim. One seed was used per tube and the trays were kept in a greenhouse for 45 days, with micro-sprinkler irrigation (58 L h-1 flow, according to the manufacturer) twice daily, for $10 \mathrm{~min}$. During the experiments, the temperature of the greenhouse ranged from 12.3 to $36{ }^{\circ} \mathrm{C}$ and the relative humidity from 26.0 to $100.0 \%$. The seeds were sown in all tubes at approximately $1.0 \mathrm{~cm}$ depth.

The volume of the tube was completed with the substrate inoculated with mycelium of Rhizoctonia solani isolate RH8, anastomosis group 4, of isolate RH8 of Rhizoctonia solani anastomosis group 4 (Silveira et al., 2000), belonging to the collection of the Laboratory of Entomology and Plant Pathology. Four experiments were conducted in a greenhouse, corresponding to the four storage periods: zero (at beginning), and after three, six and nine months. Because no symptoms of damping off were observed in seedlings in the first two periods with the isolate RH8, other isolate, RH12 of R. solani AG1- IB (Silveira et al., 2000), was used instead, in the next two experiments, at six and nine months of storage.

The mycelium was produced from cultures maintained in test tubes containing inclined potato dextrose agar (PDA) medium and subcultured with the same medium in Petri dishes. After three days of growth, the rapidly growing culture disks were transferred to $50 \mathrm{ml}$ of semisynthetic liquid medium (Alfenas et al., 1998), in 150 ml Erlenmeyer flasks and maintained at $25^{\circ} \mathrm{C}$ in the dark and left at rest. After four days of incubation, the mycelial mass was pressed between sheets of filter paper to remove excess medium, weighed and crushed in mineral water to $1 \mathrm{~g}$ mycelium L-1 water using a high-shear mixer. The ground mycelium suspension was mixed to the substrate ( $1 \mathrm{~g}$ mycelium kg-1 substrate) manually and the infested substrates were used to coat the seeds as described above.

The experiment was arranged in randomized block design with three replications in a $2 \times 5 \times 4$ factorial corresponding to two storage conditions, five fungicide treatments (captan, tolylfluanid, captan + tolylfluanid, without fungicide treatment in infested substrate and without fungicide treatment in non-infested substrate) and four storage periods ( $0,3,6$ and 9 months).

The following evaluations were performed:

a) Plant emergence: determined by daily counting of number of seedlings that emerged, considered as emerged when they broke through the substrate, forming an angle of $90^{\circ}$ with the surface.

b) Emergence Speed Index: estimated by the number of seedlings that emerged daily and recorded always at the same time of the day until reach the maximum emergence and calculated according to Maguire (1962).

c) Average height: obtained from 16 random plants per replication $45 \mathrm{~d}$ after sowing, with a ruler graduated in milimeter.

d) Shoot dry weight: obtained from two samples of eight seedlings cut at the collar region, dried for $48 \mathrm{~h}$ in oven forced air circulation at $70 \pm 1{ }^{\circ} \mathrm{C}$ in paper bags and weighed.

e) Seedling damping off at pre-(DPre) and postemergence (DPos): the percentage of damping off is determined using the equations DPre $=[(\mathrm{CA}-\mathrm{NP}) / \mathrm{CA}] \mathrm{x}$ 100 and DPOS $=[(\mathrm{CA}-\mathrm{DP}) / \mathrm{CA}] \times 100$, where $\mathrm{CA}=$ average emergence of control in non-infested substrate; NP = number of plants which emerged in the treatment; and $\mathrm{DP}=$ number of dead plants or with symptoms of disease in the treatment.

Data were subjected to analysis of variance $(\mathrm{F}=5 \%)$. Because the change of pathogen isolate (RH8 per RH12) the storage periods were compared independently by a mean comparison Tukey's test at 5\% probability.

\section{RESULTS AND DISCUSSION}

\section{Seed quality}

The water content of seeds in permeable kraft bags and stored in the laboratory varied during storage (Table 1) in order to reach the equilibrium moisture content. There was no change in the moisture content of seeds in impermeable packaging (aluminum coated paper). In this study, possible changes in seed quality cannot be attributed to moisture content, since it remained within the acceptable range for storage of papaya seeds, between 7 and $11 \%$ wb.

Table 1. Moisture content of papaya seeds without treatment (\% wb) during the storage period in two packaging materials and two environmental conditions

\begin{tabular}{|c|c|c|}
\hline \multirow[b]{2}{*}{$\begin{array}{l}\text { Storage period } \\
\text { (months) }\end{array}$} & \multicolumn{2}{|c|}{ Storage conditions } \\
\hline & $\begin{array}{c}\text { Permeable kraft } \\
\text { paper, in } \\
\text { laboratory }\end{array}$ & $\begin{array}{l}\text { Aluminum coated } \\
\text { paper, in BOD } \\
\left(7 \pm 1^{\circ} \mathrm{C}\right)\end{array}$ \\
\hline Beginning (0) & 8.58 & 8.58 \\
\hline 3 & 9.29 & 8.60 \\
\hline 6 & 9.93 & 8.59 \\
\hline 9 & 10.60 & 8.66 \\
\hline
\end{tabular}


The Blotter-test performed on seeds without fungicide treatment showed contamination by fungi and bacteria less than $5 \%$ in all periods of storage. The fungal genera found were Fusarium, Rhizopus, Penicillium and Aspergillus.

The relatively low seed contamination can be attributed to the removal of the sarcotesta, the main source of nutrients for micro-organisms in papaya seeds. Posse et al. (2003) observed increased incidence of fungi in papaya seeds, up to $20 \%$, when they had the sarcotesta compared with seeds without it. According to Menten (1995), the occurrence of certain pathogens in seeds, even in relatively low rates, can cause large losses in production. Thus, the preventive diagnosis of possible pathogens and seed treatment can help control the diseases and prevent stand reduction.

The germination test showed no change in the percentage of germination of seeds stored in permeable paper and in the laboratory, untreated or treated with the fungicide captan and the mixture captan+tolylfluanid (Figure 1a). The treatment with tolylfluanid reduced average germination from 95 to $86 \%$, after nine months of storage. Despite this reduction, toxicity symptoms were not observed in seeds.

The germination rate of seeds treated and stored in aluminum coated paper and BOD at $7 \pm 1{ }^{\circ} \mathrm{C}$ was maintained throughout the storage period (Figure $1 \mathrm{~b}$ ). Fungicides and doses used were not toxic to the seeds in these conditions, since in the germination test there were no abnormal seedlings, which could characterize phytotoxicity. However, there was a reduction in the rate of seed germination in the control without treatment, between three and six months of storage.

The potential for seed germination was not increased with the fungicide treatment and the storage, contradicting the conclusions of Aroucha et al. (2005), who found that the storage of papaya seeds for 30 days increased the percentage of germination.

In the first germination count, the seeds treated with tolylfluanid and maintained in permeable bags showed significant difference from the other treatment counts during the storage, with the point of maximum between three and six months (Figure 1c). There was no statistical difference for the other treatments.

The control seeds in aluminum coated paper showed no significant difference over the storage (Figure 1d). In the same storage conditions, there was reduction in the first germination count for the treatments captan and captan+tolylfluanid, up to three months. The treatment with tolylfluanid showed an increase over the storage time, reaching up to $90 \%$ of germination in the first count.

There was reduction in vigor for the control and the tolylfluanid treatment with decreasing responses in the accelerated aging test for seeds packed in permeable bags (Figure 1e). When the seeds were stored in aluminum coated paper, the result of the accelerated aging test showed that the vigor was maintained in the seeds treated with captan and captan+tolylfluanid, as well as the seeds in the control (Figure 1f). There was reduction in seed vigor for the treatment with tolylfluanid, between three and six months of storage, for the accelerated aging test.

\section{Damping off control}

During storage, there were no significant differences in plant emergence among the treatments captan, tolylfluanid, captan+tolylfluanid and control with noninfested substrate for both packages (Table 2). However, the emergence mean in the control with infested substrate was lower than all the treatments, when the analysis was conducted at six and nine months after storage. The lowest means of the control with infested substrate, between six and nine months, reflect the lower emergence of plants in this period because of the damping off (Table 2).

The results show that the fungicides, at the doses used in the study, favored plant emergence. When seeds were treated with captan, there was an increase in emergence between 54 and $99 \%$ compared with untreated seeds in infested substrate. The treatment with tolylfluanid showed emergence up to $100 \%$ higher than the control in the presence of the pathogen.

Several authors have reported increased plant emergence when seeds were treated with fungicides in comparison with untreated controls, for instance, Santos et al. (2010) in seeds of Brachiaria brizantha, cv. Marandu; Goulart (2008) in cotton (Gossypium hirsutum L.); Posse (2005) in papaya seeds of Solo group (Carica papaya cv. Golden.) and Formosa (Tainung 01); Pinto (2002) in sorghum (Sorghum bicolor cv. 182R CMS), among others.

The emergence speed indices (ESI) are shown in Table 3. Significant differences in ESI were found for seeds stored in permeable bags, among treatments, at the beginning and after three months of storage, only for the control with non-infested substrate. At six and nine months of storage, all treatments, including the control with non-infested substrate, exceeded the control with infested substrate. ESI decreased in the treatments tolylfluanid, captan+tolylfluanid and control with noninfested substrate, when evaluated at three months of storage. It is possible that this reduction has occurred because of the climatic conditions of winter, with milder temperatures. In this case, the reduction in the plant metabolism may have caused delayed emergence and reduction in the speed index. 
There were no significant differences among the ESI means of treatments for seeds stored in aluminum coated paper at $7 \pm 1{ }^{\circ} \mathrm{C}$, at the beginning and after three months of storage, as it was found for the seeds in permeable bags, except for the control with infested substrate. The comparison among storage periods showed that the ESI
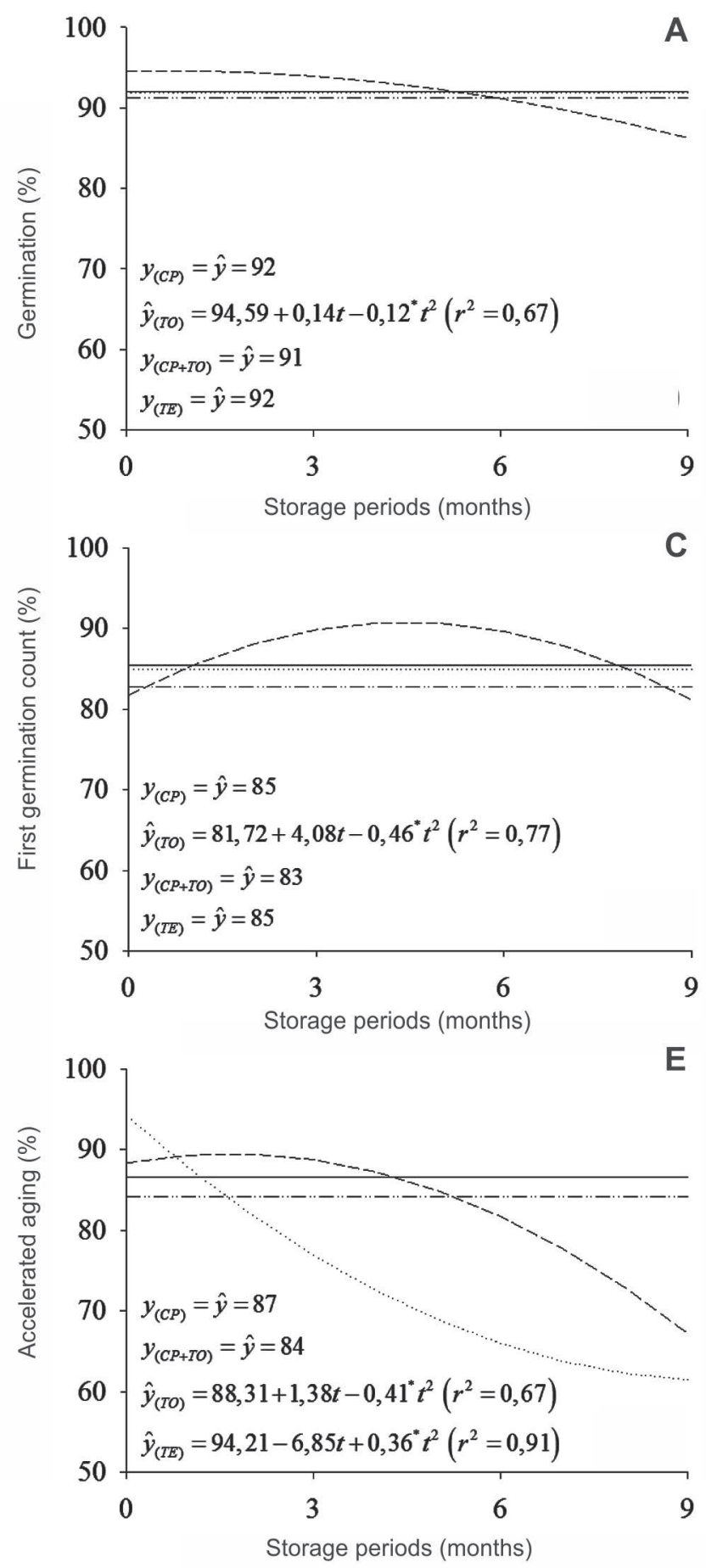

E

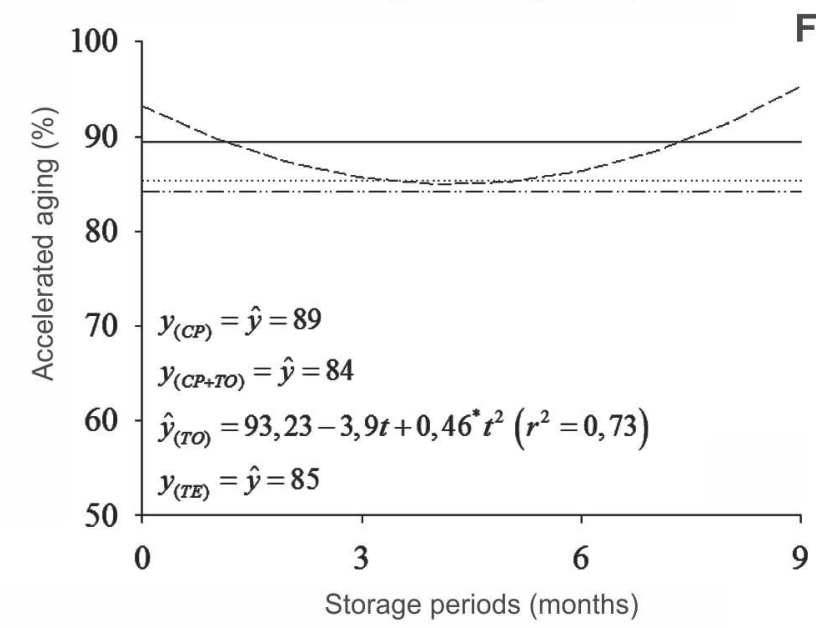

at nine months, except for the control with infested substrate, exceeded the means of the other periods for all treatments. The highest ESI reached at nine months was due to the rapid plant emergence, which was possibly favored by the higher temperatures of this period.
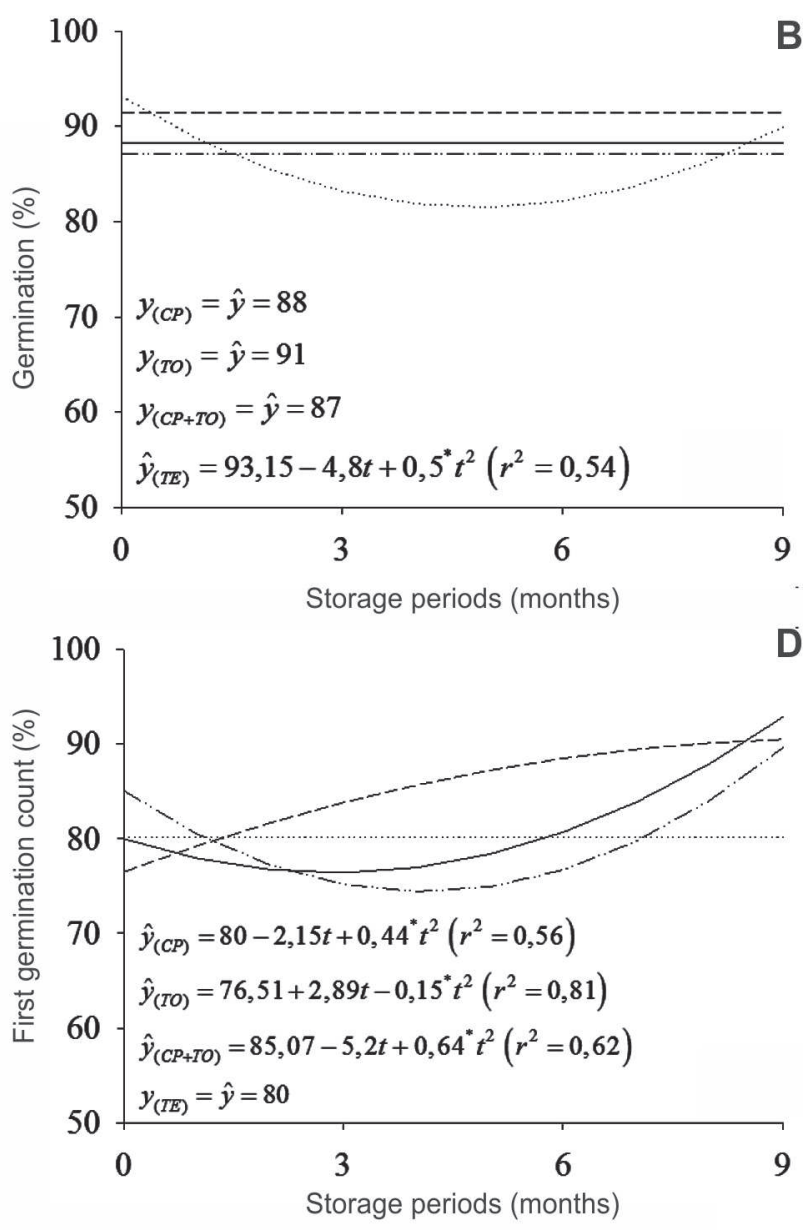

TO $-\cdot \cdots-\cdot \cdot \mathrm{CP}+\mathrm{TO}$

Figure 1. Germination (A, B) first count (C, D) and accelerated aging (E, F) of papaya seeds treated with fungicide and stored for nine months in permeable paper $(\mathrm{A}, \mathrm{C}, \mathrm{E})$ and aluminum coated paper $(\mathrm{B}, \mathrm{D}, \mathrm{F}) . \mathrm{CO}=$ control, $\mathrm{CP}=$ captan, $\mathrm{TO}=$ tolylfluanid, $\mathrm{CP}+\mathrm{TO}$ $=$ captan + tolylfluanid. 
The height of plants derived from seeds stored in permeable bags was not significantly different among the treatments in the four storage periods (Table 4). However, during storage, only the treatment with captan, with seeds stored in permeable bags, had no significant differences. For all other treatments, the mean height of the initial storage period exceeded the means of the other periods.

For seeds stored in aluminum coated paper, the ean height of plants in the control with non-infested substrate exceeded all other treatments at the beginning of storage (Table 4), whereas after three months, they had the lowest means. At six and nine months, there was no difference among treatments. Throughout the storage, there was significant difference only for the control with noninfested substrate and the means achieved in the initial period exceeded the means of the other storage periods, which showed no significant differences.

The analysis of variance showed no significant differences in shoot dry weight over the period of storage and among treatments for both conditions of storage, indicating uniformity of sowing conditions in all periods evaluated.
No symptoms of damping off or death of plants caused by the pathogen added to the substrate were observed at the beginning and at three months of storage (Table 5). For both types of packaging, at six and nine months of storage, there were no significant differences among fungicides and the control with non-infested substrate, but these were significantly different from the control with infested substrate, which had a high rate of damping off.

The fungicides used at the doses tested were efficient in controlling pre-emergence damping off after nine months of seed storage in permeable paper or aluminum coated paper. The incidence of pre-emergence damping off in fungicide treatments were lower than $3 \%$, except for the treatment tolylfluanid in permeable paper bags that had $7.22 \%$ of damping off seedlings in the evaluation at six months (Table 5) .

Similar results were obtained by Posse (2005) in the control of damping-off caused by Rhizoctonia spp using the treatment of papaya seeds and also by Goulart et al. (2000) and Goulart (2002) in cotton seeds. According to Goulart (2002), several fungal species cause damping off, but only Rhizoctonia spp. causes plant to collapse in preand post-emergence. The same author observed that the increase in emergence, in treatments with fungicides, can

Table 2. Plant emergence (\%) from papaya seeds treated, packaged and stored in two environmental conditions for nine months

\begin{tabular}{|c|c|c|c|c|c|c|c|c|}
\hline \multirow{3}{*}{ Treat } & \multicolumn{4}{|c|}{$\begin{array}{c}\text { Permeable kraft paper } \\
\text { in non-controlled environment }\end{array}$} & \multicolumn{4}{|c|}{$\begin{array}{l}\text { Aluminum coated paper, } \\
\text { in } \mathrm{BOD}\left(7 \pm 1^{\circ} \mathrm{C}\right)\end{array}$} \\
\hline & \multicolumn{8}{|c|}{ Storage period (months) } \\
\hline & $\mathbf{0}^{*}$ & 3 & 6 & 9 & $\mathbf{0}^{*}$ & 3 & 6 & 9 \\
\hline$\overline{\mathrm{CP}}$ & $94 \mathrm{aA}$ & $92 \mathrm{aA}$ & $87 \mathrm{aA}$ & $83 \mathrm{aA}$ & $91 \mathrm{aA}$ & $92 \mathrm{aA}$ & $87 \mathrm{aA}$ & $91 \mathrm{aA}$ \\
\hline TO & $93 \mathrm{aA}$ & $90 \mathrm{aA}$ & $93 \mathrm{aA}$ & $87 \mathrm{aA}$ & $93 \mathrm{aA}$ & $93 \mathrm{aA}$ & $91 \mathrm{aA}$ & $91 \mathrm{aA}$ \\
\hline $\mathrm{CT}$ & $92 \mathrm{aA}$ & $93 \mathrm{aA}$ & $92 \mathrm{aA}$ & $87 \mathrm{aA}$ & $95 \mathrm{aA}$ & $93 \mathrm{aA}$ & $88 \mathrm{aA}$ & $88 \mathrm{aA}$ \\
\hline CI & $94 \mathrm{aA}$ & $89 a A$ & $49 \mathrm{bB}$ & $45 \mathrm{bB}$ & $93 \mathrm{aA}$ & $94 \mathrm{aA}$ & $43 \mathrm{cB}$ & $59 \mathrm{bB}$ \\
\hline $\mathrm{CNI}$ & $94 \mathrm{aA}$ & $89 \mathrm{aA}$ & $97 \mathrm{aA}$ & $88 \mathrm{aA}$ & $92 \mathrm{aA}$ & $87 \mathrm{aA}$ & $93 \mathrm{aA}$ & $91 \mathrm{aA}$ \\
\hline
\end{tabular}

Means followed by the same small letters in the row and capital letters in the column, for each storage condition, are not different at 5\% probability by the Tukey's test. $\mathrm{CP}=$ captan; $\mathrm{TO}=$ tolylfluanid; $\mathrm{CT}=$ captan+tolylfluanid; $\mathrm{CI}=$ control with infested substrate; and $\mathrm{CNI}$ $=$ control with non-infested substrate. ${ }^{*}$ The storage period zero $(0)$ corresponds to the analysis carried out immediately after extraction and drying of seeds.

Table 3. Emergence speed index of plants derived from papaya seeds treated, packaged and stored in two environmental conditions for nine months

\begin{tabular}{|c|c|c|c|c|c|c|c|c|}
\hline \multirow{3}{*}{ Treat } & \multicolumn{4}{|c|}{$\begin{array}{c}\text { Permeable kraft paper } \\
\text { in non-controlled environment }\end{array}$} & \multicolumn{4}{|c|}{$\begin{array}{l}\text { Aluminum coated paper, } \\
\text { in } \mathrm{BOD}\left(7 \pm 1^{\circ} \mathrm{C}\right)\end{array}$} \\
\hline & \multicolumn{8}{|c|}{ Storage period (months) } \\
\hline & $\mathbf{0}^{*}$ & 3 & 6 & 9 & $\mathbf{0}^{*}$ & 3 & 6 & 9 \\
\hline$\overline{\mathrm{CP}}$ & $6.2 \mathrm{aA}$ & $5.3 \mathrm{aA}$ & $6.0 \mathrm{aA}$ & $6.2 \mathrm{aA}$ & $6.1 \mathrm{bA}$ & $5.5 \mathrm{bA}$ & $5.9 \mathrm{bA}$ & $8.1 \mathrm{aA}$ \\
\hline TO & 6.0abA & $5.4 \mathrm{bA}$ & $6.6 \mathrm{aA}$ & $6.5 \mathrm{aA}$ & $6.3 \mathrm{bA}$ & $5.2 \mathrm{bA}$ & $6.2 \mathrm{bA}$ & $7.9 \mathrm{aA}$ \\
\hline $\mathrm{CT}$ & 5.9abA & $5.2 \mathrm{bA}$ & $6.4 \mathrm{aA}$ & $6.3 \mathrm{aA}$ & $6.3 \mathrm{abA}$ & $5.5 \mathrm{bA}$ & $6.0 \mathrm{bA}$ & $7.3 \mathrm{aA}$ \\
\hline $\mathrm{CI}$ & $6.2 \mathrm{aA}$ & $5.7 \mathrm{aA}$ & $3.3 \mathrm{bB}$ & $3.6 \mathrm{bB}$ & $6.4 \mathrm{aA}$ & $4.7 \mathrm{bA}$ & $3.0 \mathrm{cB}$ & $5.1 \mathrm{bB}$ \\
\hline $\mathrm{CNI}$ & $6.2 \mathrm{aA}$ & $4.9 \mathrm{bA}$ & 7.1aA & $6.7 \mathrm{aA}$ & $6.1 \mathrm{bcA}$ & $5.3 \mathrm{cA}$ & $6.7 \mathrm{bA}$ & $7.8 \mathrm{aA}$ \\
\hline
\end{tabular}

Means followed by the same small letters in the row and capital letters in the column, for each storage condition, are not different at 5\% probability by the Tukey's test. $\mathrm{CP}=$ captan; $\mathrm{TO}=$ tolylfluanid; $\mathrm{CT}=$ captan+tolylfluanid; $\mathrm{CI}=$ control with infested substrate; and $\mathrm{CNI}$ $=$ control with non-infested substrate. 
be attributed to an indirect effect of the control of this fungus in the substrate, for providing a region around the seed that is pathogen free and favorable to the emergence.

All treatments were statistically different from the control with non-infested substrate at six and nine months for the percentage of post-emergence damping off, since disease symptoms were not observed in plants of this control treatment in both conditions of seed storage (Table 6).
Plants derived from seeds treated with captan+tolylfluanid and stored in permeable paper for six months of storage had the highest rate of post-emergence damping off, with $33.1 \%$ of collapsed plants. However, there were no significant differences among this treatment and the control with infested substrate and the treatment with captan. At nine months, the treatment with tolylfluanid had $33.4 \%$ of damping off, exceeding the percentage of the control with infested substrate (Table 6).

Table 4. Mean height $(\mathrm{cm})$ of plants derived from papaya seeds treated, packaged and stored in two environmental conditions for nine months

\begin{tabular}{|c|c|c|c|c|c|c|c|c|}
\hline \multirow{3}{*}{ Treat } & \multicolumn{4}{|c|}{$\begin{array}{c}\text { Permeable kraft paper } \\
\text { in non-controlled environment }\end{array}$} & \multicolumn{4}{|c|}{$\begin{array}{l}\text { Aluminum coated paper, } \\
\text { in BOD }\left(7 \pm 1^{\circ} \mathrm{C}\right)\end{array}$} \\
\hline & \multicolumn{8}{|c|}{ Storage period (months) } \\
\hline & $\mathbf{0}^{*}$ & 3 & 6 & 9 & $\mathbf{0}^{*}$ & 3 & 6 & 9 \\
\hline$\overline{\mathrm{CP}}$ & $5.4 \mathrm{aA}$ & $4.3 \mathrm{aA}$ & $4.8 \mathrm{aA}$ & $5.4 \mathrm{aA}$ & $4.8 \mathrm{aB}$ & $4.7 \mathrm{aAB}$ & $4.7 \mathrm{aA}$ & $5.7 \mathrm{aA}$ \\
\hline TO & $6.3 \mathrm{aA}$ & $4.2 \mathrm{bA}$ & $4.8 \mathrm{bA}$ & $5.2 \mathrm{abA}$ & $5.5 \mathrm{aB}$ & $4.4 \mathrm{aAB}$ & $5.1 \mathrm{aA}$ & $5.6 \mathrm{aA}$ \\
\hline $\mathrm{CT}$ & $6.1 \mathrm{aA}$ & $4.1 \mathrm{cA}$ & $4.8 \mathrm{bcA}$ & $5.4 \mathrm{abA}$ & $4.7 \mathrm{aB}$ & $5.6 \mathrm{aA}$ & $5.5 \mathrm{aA}$ & $5.6 \mathrm{aA}$ \\
\hline $\mathrm{CI}$ & $6.1 \mathrm{aA}$ & $4.4 \mathrm{bA}$ & $4.4 \mathrm{bA}$ & $4.5 \mathrm{bA}$ & $5.1 \mathrm{aB}$ & $4.4 \mathrm{aAB}$ & $4.8 \mathrm{aA}$ & $5.1 \mathrm{aA}$ \\
\hline $\mathrm{CNI}$ & $6.5 \mathrm{aA}$ & $4.0 \mathrm{bA}$ & $4.9 \mathrm{bA}$ & $5.1 \mathrm{bA}$ & $7.0 \mathrm{aA}$ & $4.2 \mathrm{bB}$ & $5.2 \mathrm{bA}$ & $5.1 \mathrm{bA}$ \\
\hline
\end{tabular}

Means followed by the same small letters in the row and capital letters in the column, for each storage condition, are not different at $5 \%$ probability by the Tukey's test. $\mathrm{CP}=$ captan; $\mathrm{TO}=$ tolylfluanid; $\mathrm{CT}=$ captan+tolylfluanid; $\mathrm{CI}=$ control with infested substrate; and $\mathrm{CNI}$ $=$ control with non-infested substrate.

Table 5. Pre-emergence damping off (\%) of plants derived from papaya seeds treated, packaged and stored in two environmental conditions for nine months

\begin{tabular}{|c|c|c|c|c|c|c|c|c|}
\hline \multirow{3}{*}{ Treat } & \multicolumn{4}{|c|}{$\begin{array}{c}\text { Permeable kraft paper } \\
\text { in non-controlled environment }\end{array}$} & \multicolumn{4}{|c|}{$\begin{array}{l}\text { Aluminum coated paper, } \\
\text { in BOD }\left(7 \pm 1^{\circ} \mathrm{C}\right)\end{array}$} \\
\hline & \multicolumn{8}{|c|}{ Storage period (months) } \\
\hline & $\mathbf{0}^{*}$ & 3 & 6 & 9 & $\mathbf{0}^{*}$ & 3 & 6 & 9 \\
\hline$\overline{\mathrm{CP}}$ & $0.0 \mathrm{aA}$ & $0.0 \mathrm{aA}$ & $2.1 \mathrm{aB}$ & $2.3 \mathrm{aB}$ & $0.0 \mathrm{aA}$ & $0.0 \mathrm{aA}$ & $2.7 \mathrm{aB}$ & $1.8 \mathrm{aB}$ \\
\hline TO & $0.0 \mathrm{aA}$ & $0.0 \mathrm{aA}$ & $7.2 \mathrm{aB}$ & $1.6 \mathrm{aB}$ & $0.0 \mathrm{aA}$ & $0.0 \mathrm{aA}$ & $1.9 \mathrm{aB}$ & $0.8 \mathrm{aB}$ \\
\hline $\mathrm{CT}$ & $0.0 \mathrm{aA}$ & $0.0 \mathrm{aA}$ & $1.6 \mathrm{aB}$ & $2.1 \mathrm{aB}$ & $0.0 \mathrm{aA}$ & $0.0 \mathrm{aA}$ & $0.9 \mathrm{aB}$ & $2.7 \mathrm{aB}$ \\
\hline CI & $0.0 \mathrm{bA}$ & $0.0 \mathrm{bA}$ & $46.7 \mathrm{aA}$ & $48.8 \mathrm{aA}$ & $0.0 \mathrm{bA}$ & $0.0 \mathrm{bA}$ & $35.1 \mathrm{aA}$ & $36.2 \mathrm{aA}$ \\
\hline $\mathrm{CNI}$ & $0.0 \mathrm{aA}$ & $0.0 \mathrm{aA}$ & $0.0 \mathrm{aB}$ & $0.0 \mathrm{aB}$ & $0.0 \mathrm{aA}$ & $0.0 \mathrm{aA}$ & $0.0 \mathrm{aB}$ & $0.0 \mathrm{aB}$ \\
\hline
\end{tabular}

Means followed by the same small letters in the row and capital letters in the column, for each storage condition, are not different at $5 \%$ probability by the Tukey's test. $\mathrm{CP}=$ captan; $\mathrm{TO}=$ tolylfluanid; $\mathrm{CT}=$ captan+tolylfluanid; $\mathrm{CI}=$ control with infested substrate; and $\mathrm{CNI}$ $=$ control with non-infested substrate.

Table 6. Post-emergence damping off (\%) of plants derived from papaya seeds treated, packaged and stored in two environmental conditions for nine months

\begin{tabular}{|c|c|c|c|c|c|c|c|c|}
\hline \multirow{3}{*}{ Treat } & \multicolumn{4}{|c|}{$\begin{array}{c}\text { Permeable kraft paper } \\
\text { in non-controlled environment }\end{array}$} & \multicolumn{4}{|c|}{$\begin{array}{l}\text { Aluminum coated paper, } \\
\text { in } \mathrm{BOD}\left(7 \pm 1^{\circ} \mathrm{C}\right)\end{array}$} \\
\hline & \multicolumn{8}{|c|}{ Storage period (months) } \\
\hline & 0* & 3 & 6 & 9 & 0* & 3 & 6 & 9 \\
\hline$\overline{\mathrm{CP}}$ & $0.0 \mathrm{bA}$ & $0.0 \mathrm{bA}$ & $22.0 \mathrm{aAB}$ & $22.2 \mathrm{aAB}$ & $0.0 \mathrm{aA}$ & $0.0 \mathrm{aA}$ & $2.7 \mathrm{aB}$ & $1.8 \mathrm{aB}$ \\
\hline TO & $0.0 \mathrm{cA}$ & $0.0 \mathrm{cA}$ & $20.9 \mathrm{bB}$ & $33.4 \mathrm{aA}$ & $0.0 \mathrm{aA}$ & $0.0 \mathrm{aA}$ & $1.9 \mathrm{aB}$ & $0.8 \mathrm{aB}$ \\
\hline $\mathrm{CT}$ & $0.0 \mathrm{bA}$ & $0.0 \mathrm{bA}$ & $33.1 \mathrm{aA}$ & $22.1 \mathrm{aAB}$ & $0.0 \mathrm{aA}$ & $0.0 \mathrm{aA}$ & $0.9 \mathrm{aB}$ & $2.7 \mathrm{aB}$ \\
\hline CI & $0.0 \mathrm{bA}$ & $0.0 \mathrm{bA}$ & $22.8 \mathrm{aAB}$ & $21.0 \mathrm{aB}$ & $0.0 \mathrm{bA}$ & $0.0 \mathrm{bA}$ & $35.1 \mathrm{aA}$ & $36.2 \mathrm{aA}$ \\
\hline $\mathrm{CNI}$ & $0.0 \mathrm{aA}$ & $0.0 \mathrm{aA}$ & $0.0 \mathrm{aC}$ & $0.0 \mathrm{aC}$ & $0.0 \mathrm{aA}$ & $0.0 \mathrm{aA}$ & $0.0 \mathrm{aB}$ & $0.0 \mathrm{aB}$ \\
\hline
\end{tabular}

Means followed by the same small letters in the row and capital letters in the column, for each storage condition, are not different at $5 \%$ probability by the Tukey's test. $\mathrm{CP}=$ captan; $\mathrm{TO}=$ tolylfluanid; $\mathrm{CT}=$ captan+tolylfluanid; $\mathrm{CI}=$ control with infested substrate; and $\mathrm{CNI}$ $=$ control with non-infested substrate.

Rev. Ceres, Viçosa, v. 61, n.3, p. 384-391, mai/jun, 2014 
The results for damping off incidence, equal and even higher than the control with infested substrate, occurred because the fungicides were effective in controlling the preemergence damping off, providing greater amount of substrate (plant tissues) to be colonized by the fungus after emergence.

There were no significant differences for postemergence damping off among the fungicide treatments and the control with non-infested substrate, when the seeds were stored in aluminum coated paper and kept in BOD at $7 \pm 1{ }^{\circ} \mathrm{C}$ (Table 6). However, all treatments differed from the control with infested substrate. It was found that the tested fungicides were not effective in controlling post-emergence damping off. This is explained by the nature of the products used, which are protective or contact fungicides.

Goulart (2002) reported a lower post-emergence damping off in cotton plants treated with fungicide mixtures compared with the use of a particular product alone. In this study, however, we found no differences in rates of damping off when the seeds were treated with the mixture or with isolated protective fungicides.

It was found, moreover, that there was no incidence of pre- or post-emergence damping off when the seeds were sown on non-infested substrate. Thus, the use of substrate without contamination was an important of disease control measure to be adopted, aiming to lower production cost and higher quality seedlings.

Other measures that can reduce the incidence of seedling damping off are the use of inoculum-free tubes and trays and the daily removal of failed tubes or tubes with diseased plants. This removal is necessary, especially when dealing with with Rhizoctonia solani AG1-IB, because isolates of this species have epiphytic growth, i.e., they are able to grow in the plant shoots and thus be transferred from one tube to another (secondary dissemination) (Silveira et al., 2000).

\section{CONCLUSIONS}

The fungicides and doses used in this study were not toxic to papaya seeds and contributed to the maintenance of their high quality, for at least nine months. All fungicide treatments were effective in the control of pre-emergence damping off. The use of pathogen-free substrate, followed by the chemical treatment, is an effective measure to guarantee the production of healthy papaya seedlings.

\section{REFERENCES}

Alfenas AC, Brune W, Oliveira JR, Kunieda-Dealonso S \& Scortichini M (1998) Extração de proteínas para eletroforese. In: Alfenas AC (Ed.) Eletroforese de Isoenzimas e Proteínas Afins: Fundamentos e Aplicações em Plantas e Microrganismos. Viçosa, Editora UFV. p.85-114.
Aroucha EMM, Silva RF, Oliveira JG, Viana AP \& Gonzaga MP (2005) Época de colheita e período de repouso dos frutos de mamão (Carica papaya L.) cv. Golden na qualidade fisiológica das sementes. Ciência Rural, 35:537-543.

Bedendo IP (1995) Damping off. In: Kimati, H et al. (Ed.) Manual de Fitopatologia. $3^{\text {a }}$ Ed. São Paulo, Agronômica Ceres. p.820-828.

Brasil (1992) Ministério da Agricultura e Reforma Agrária. Secretaria Nacional de Defesa Agropecuária. Departamento Nacional de Defesa Vegetal. Coordenação de Laboratório Vegetal. Regras para Análise de Sementes. Brasília, SNDA/DNDV/CLAV. $365 \mathrm{p}$.

Campos SC, Silveira SF, Silva RF, Viana AP \& Conceição PM (2009) Tratamento químico de sementes de mamão visando ao controle de Rhizoctonia solani. Tropical Plant Pathology, 34:192-197.

Embrapa - Empresa Brasileira de pesquisa Agropecuária (2012) Perguntas e Respostas: Mamão. Disponível em: <http:// www.cnpmf.embrapa.br/index.php?p=perguntas_e_respostasmamao.php>. Acessado em: 23 de maio de 2012.

Goulart ACP (2002) Efeito do tratamento de sementes de algodão com fungicidas no controle do tombamento de plântulas causado por Rhizoctonia solani. Fitopatologia Brasileira, 27:399-402.

Goulart ACP (2008) Efeito do tratamento de sementes de algodoeiro com fungicidas no controle do tombamento de plântulas causado por Rhizoctonia solani, sob condições de casa de vegetação. Tropical Plant Pathology, 33:394-398.

Goulart ACP, Andrade PJM \& Borges EP (2000) Controle do tombamento de plântulas do algodoeiro causado por Rhizoctonia solani pelo tratamento de sementes com fungicidas. Summa Phytopathologica, 26:362-368.

Maguire JD (1962) Seed germination-aid in selection and evaluation for seedling emergence and vigour. Crop Science, 2:176-177.

Menten JOM (1995) Prejuízos causados por patógenos associados às sementes. In: Menten, JOM (Ed.) Patógenos em Sementes: Detecção, danos e controle químico. São Paulo, Ciba Agro. p.114-136.

Neergaard P (1979) Seed pathology. London, MacMillan Press. $1191 \mathrm{p}$.

Oliveira AAR, Barbosa CJ, Santos Filho HP \& Meissner Filho PE (2000) Doenças e seu controle. In: Trindade AV (Ed.) Mamão. Produção: aspectos técnicos. Brasília, Embrapa. p.43-52.

Oliveira AAR \& Santos Filho HP (2000) Doenças. In: Ritzinger CHS \& Souza JS (Ed.) Mamão, fitossanidade. Cruz das Almas, Embrapa Comunicação para Transferência de Tecnologia. p.37-46.

Pinto NFJA (2002) Controle químico de fungos associados a sementes de sorgo e proteção contra fungos do solo. Pesquisa Agropecuária Brasileira, 37:723-728.

Posse SCP (2005) Produção de mudas do mamoeiro: tratamento da semente, substrato e condicionamento mecânico. Tese de Doutorado. Universidade Estadual do Norte Fluminense, Campos dos Goytacazes. 130p.

Posse SCP, Silva RF, Silveira SF, Silva MP \& Martins GN (2003) Análise patológica e tratamento de sementes de mamão com fungicidas. In: Congresso Brasileiro de Sementes, Londrina. Anais, Abrates. p.231.

Santos FC, Oliveira JA, Von Pinho EVR, Guimarães RM \& Vieira AR (2010) Tratamento químico, revestimento e armazenamento de sementes de Brachiaria brizantha cv. Marandu. Revista Brasileira de Sementes, 32:69-78.

Silveira SF, Alfenas AC, Ferreira FA \& Sutton JC (2000) Characterization of Rhizoctonia species associated with foliar necrosis and leaf scorch of clonally-propagated Eucalyptus in Brazil. European Journal of Plant Pathology, 106:27-36. 